\title{
Klumme:
}

\section{En usædvanlig mand}

\section{Af Klaus Carsten Pedersen}

Ole Lippmann var en af modstandskampens ledende skikkelser og den egentlige ophavsmand til Det Udenrigspolitiske Selskab. Dette er den nekrolog Selskabets daværende direktør skrev ved Ole Lippmanns død den 3. september 2002.

Ole Lippmann var en ganske usædvanlig mand. Han besad en sjælden kombination af mod og mandshjerte, sund sans og snarrådighed, humor og handlekraft, varme og skarphed, socialt engagement og politisk overblik. Han var født i 1916, og fik tidligt udviklet sine evner og sin karakter gennem en praktisk uddannelse i familiefirmaet, handelsuddannelse på Niels Brock og studieophold i England i 1935 og USA i 1936-37 og ikke mindst en hjemrejse i 1937 via Japan, et krigshærget Kina og et Moskva i færd med den store udrensning. Tidligt fik han set meget af verden, og tidligt blev han vaccineret mod enhver form for totalitær ideologi.

Han sluttede sig som en selvfølge til modstandsbevægelsen, hvor han bl.a. lærte Svend Truelsen at kende, og da denne efter 29. august 1943 blev leder af den militære efterretningstjeneste, gled han med over i dette arbejde. Han fik bl.a. hovedansvaret for de ugentlige politiske efterretningsrapporter, der gik via Sverige til England, og som Hæstrup siden vurderede som en hovedkilde til tidens historie. I juli 1944 blev han beordret til London for at blive uddannet ved Special Forces og ved Special Operations Executive's (SOE's) danske sektion.

Ved befrielsen den 4. maj 1945, var han netop fyldt 29. Han havde da i tre måneder været faldskærmschef og dermed de allieredes øverste repræsentant i Danmark med rang af major i den britiske hær. Han havde været de allieredes 'observatør' i Frihedsrådet og medlem af rådets Kommandoudvalg. Det var lykkedes ham at samle den splittede modstandsbevægelse, gøre klar til den kamp, der kunne komme, og samtidig forberede en fredelig og ordnet overgang til civilt styre efter befrielsen. Og da general Dewing som den første britiske soldat satte foden på dansk jord den 5. maj, var det Ole Lippmann, som tog imod ham i lufthavnen.

Ole Lippmanns militære mål var nået med de allieredes sejr og Danmarks befrielse. Hans sikkerhedspolitiske mål havde i første omgang været at få Dan-

Klaus Carsten Pedersen er cand. polit. Han var Det Udenrigspolitiske Selskabs direktør fra 1987-2013. 
mark anerkendt som allieret. Også det var nået, bl.a. som følge af hans egen energiske indsats. I næste omgang gjaldt det om at sikre, at Danmark efter krigen ikke gled tilbage i neutralitet og isolation, men fastholdt og befæstede sin nyvundne status som allieret med primært Storbritannien og USA. Da jerntæppet, med Churchills ord, sænkede sig over Europa, var det afgørende, at Danmark var solidt forankret i Vest. Ole Lippmann havde gjort, hvad han kunne for at lægge tingene til rette i de sidste krigsmåneder, hvor hans indflydelse var meget betydelig; men da den militære sejr var vundet, havde han løst sin opgave, og andre kræfter tog over.

Lettet for det kolossale ansvar, han havde båret, vendte han tilbage til ledelsen af familiefirmaet, som han drev frem til en blomstrende international virksomhed. Han gik ikke ind i politik, men fastholdt livet igennem sit stærke humanitære og sikkerhedspolitiske engagement. Sammen med vennen fra Frihedsrådet Erik Husfeldt organiserede han under Ungarns opstand mod Sovjetunionen i efteråret 1956 på få dage UngarnAmbulancen. Et andet eksempel var hans stadige interesse for Polen, dets folk, historie, litteratur og film. Han så det som et grænseland af afgørende betydning for Vesteuropas skæbne. Han lavede et datterselskab, en lille fabrik i Polen for medicinalvarer og hospitalsudstyr, og han fik i tidens løb 260 polske læger, sygeplejersker og ingeniører efteruddannet i Danmark. Polen hædrede ham for hans indsats. Han blev højt dekoreret, var præsident Jaruzelskis gæst i 1989, og han blev attacheret præsident Walesa under statsbesøget i Danmark i 1995.

Et tredje eksempel var et projekt, han havde forberedt allerede i slutningen af
1944 gennem diskussioner i London med bl.a. oberstløjtnant Nordentoft: Det Udenrigspolitiske Selskab. Den officielle danske udenrigspolitik havde stort set mistet sin troværdighed og autoritet både hjemme og i udlandet, og Ole Lippmann, som altid forholdt sig naturligt skeptisk til de fleste formelle autoriteter, havde konkluderet, at udenrigspolitik øjensynlig var for vigtig til, at man helt kunne overlade den til politikerne og udenrigsministeriet. Han var inspireret af The Royal Institute of International Affairs i Chatham House i London, hvor aktuelle internationale og udenrigspolitiske spørgsmål blev gjort til genstand for kvalificeret debat i et politisk og økonomisk uafhængigt forum.

Til den kreds af tidligere modstandsfolk, som han havde fået med på idéen, sluttede sig folk fra universiteterne og erhvervslivet, og den 31. oktober 1946 kunne man holde stiftende møde. Det Udenrigspolitiske Selskabs formål blev at stimulere interessen i Danmark for udenrigspolitiske spørgsmål og bidrage til at øge den almene viden om internationale forhold. Per Federspiel blev formand, og Ole Lippmann indtog den plads i bestyrelsen, som han beholdt i næsten 56 år. I 1996 benyttede Selskabet sit 50-årsjubilæum til at gøre ham til sit første æresmedlem.

Ole Lippmann omfattede i alle disse år Det Udenrigspolitiske Selskab med levende interesse. Et fond, han var formand for, støttede år efter år Selskabet med et betydeligt beløb, og skønt den formelle tildeling først kunne ske i maj måned, sørgede han for at sende et forpligtende tilsagn $\mathrm{i}$ god tid før jul, så man vidste, hvor man stod. Han deltog aktivt i mange af Selskabets møder, og da Selskabet i 1989 planlagde sin første store studierejse, ville han med; for målet var Moskva, som han ikke 
havde set siden 1937. Han havde ganske vist kort forinden haft et hjertetilfælde og fået pacemaker, og hans læge var ikke begejstret for rejseplanerne; men han tog med alligevel, og hjertet slog støt og roligt videre i endnu tretten år. Han var også med Selskabet i Estland, Letland og Litauen i 1990, et år før de blev selvstændige. Han var med i Tjekkoslovakiet i 1992, umiddelbart før delingen, og i Gdansk, Kaliningrad og Vilnius i 1994.

Han ville meget gerne også have været med på de lange rejser til Centralasien i 1993 og Mellemøsten i 1994, men afstod. Det var karakteristisk, at han ikke var betænkelig på egne vegne, men bekymret for de svære vanskeligheder, som rejsekammeraterne kunne komme ud for, hvis noget skulle gå rigtig galt. Han var til det sidste et inspirerende bestyrelsesmedlem og en fantastisk ven; for selv om hans fysik i de seneste år begyndte at svigte ham, nåede han ikke at blive gammel.

Han fastholdt kontakten med sine danske og britiske kampfæller fra krigens tid, og ved 50-året for krigens afslutning var han den ene af de to, der repræsenterede de europæiske modstandsbevægelser ved højtideligheden i Westminster Abbey. Men det lå ham fjernt at blive hængende i historien, og han fik livet igennem nye kontakter og kampfæller og nære venner, som han var på bølgelængde med, og som han fx kunne finde på at sende bøger, der havde begejstret ham, og som han mente, de også burde læse.

En bog, man gerne ville have haft, var hans erindringer; men den blev aldrig skrevet, skønt mange opfordrede ham til det. Han ville ikke og havde sikkert sine gode grunde. Noget har vi dog på tryk, bla. et langt og levende interview med
Ninka (Politiken 19. marts 1995), som kaldte ham den blufærdige ridder af den nødvendige samvittighed. Med denne blufærdighed og med sit blik for sammenhænge og helheder fandt han historien om SOE og den danske modstandskamp vigtigere end historien om ham selv, og da SOE’s arkiver blev tilgængelige i 1994, fik han overtalt historikeren Knud J. V. Jespersen til at påtage sig opgaven. Med hjoelp fra England kom i to bind (i 1998 og 2000). Den er grundig og god, og bind 2 (Den vabnede kamp 1943-1945) er selvfølgelig også en væsentlig kilde til vor viden om den unge Ole Lippmann og hans enestående indsats i vinteren og foråret 1945.

Mod slutningen af bogen citerer forfatteren den 30-årige Ole Lippmanns 4. majtale i 1946, og han runder af med at sige, at disse nøgterne vurderinger og formaninger $i$ en vis forstand kan ses som et kort sammendrag af de situationsvurderinger, som hele den britiske og allierede planlægning af befrielsen og efterkrigstiden havde bygget på, og at de derfor kan stå som en slags samlet konklusion på skildringen af disse bestræbelser: "Var det lykkedes Modstandsbevægelsen paa basis af Krigstidens Erfaringer at samle alle de progressive Kræfter i den danske Befolkning? - I Dag, et Aar efter, kan vi roligt erkende, at det ikke er lykkedes men af den Grund behøver vi ikke at blive bitre, skuffede eller pessimistiske. Det er naturligt, at de fire Millioner Frihedskæmpere, der hilste de allierede Tropper velkomne til Danmark, i dagene efter den 5. Maj kunde faa os til at tro, at nu var Slaget vundet, og nu opstod en ny og bedre Verden. - Det der var vundet, var første Fase - Uddrivningen af Tyskerne og Retten til igen at danne en fri Rege- 
ring - men Genopbygningen af Danmark og Skabelsen af et dansk Demokrati paa Retsstatens Grundlag - et Danmark som forstaar sin Stillling som medlem af de Forenede Nationer - som forstaar, at vi maa yde for at kunne nyde - som frem for alt forstaar, at vor Frihed er det højeste og dyrebareste, vi ejer - det er en Opgave, som kræver mindst lige saa store Kræfter - lige saa megen utrættelig Energi - lige saa megen ren Idealisme." Et citat fra Ninkas interview med Ole Lippmann 49 år senere kan passende slutte dette portræt: "Jeg er grænseløst optimist. Jeg er helt i min sjæls inderste overbevist om, at verden er blevet et sikrere sted at leve efter 1989. Gud skabte orden ud af kaos, og jeg tror faenme, at han gør det een gang til. Jeg bander ned i helvede, at jeg er blevet så gammel, som jeg er. Jeg vil gerne se de næste ti år. Men jeg indrømmer, at jeg gider ikke holde med tabere. Eller, sagt på en anden måde: Jeg gider ikke spilde min tid på noget, jeg ikke tror på. Jeg er fundamentalt europæer. Lærer vi ikke at samarbejde, kan vi lige så godt pakke sammen. Så bliver vi bananrepublikker, som bekriger hinanden. Vi skal optræde som en enhed, men leve på vore forskelligheder." 
